\title{
Solitary pulmonary nodule — the role of imaging in the diagnostic process
}

The authors declare no finacial disclosure

\begin{abstract}
A solitary pulmonary nodule is a round opacity less than $30 \mathrm{~mm}$ in diameter surrounded by normally aerated lung tissue. Determination of the character of the lesion following its detection (particularly when the identification was incidental) may require a complex diagnostic process. In most cases, nodules are benign in character; however, the probability of malignancy increases significantly for part-solid lesions. The main features that describe the solitary pulmonary nodule in computed tomography scans include their size, shape, density, presence of calcification and rate of growth. PET-CT examination provides additional information on the metabolic activity of the lesions, and MRI is helpful in assessment of local invasion of surrounding structures. Due to limited availability and highly specialized character, these examinations are not routinely used. Therefore, despite development of other imaging modalities, computed tomography remains the most important and crucial diagnostic tool.

Clinical risk factors such as age or smoking status are very important for evaluation of the likelihood of malignancy of a nodular lesion. Due to the multidisciplinary nature of data required for complex assessment of a solitary nodular lesion, management routines are needed in the diagnostic process such as those proposed by the Fleischner Society.
\end{abstract}

Key words: solitary pulmonary nodule; non-solid nodule; management strategy; chest imaging; lung neoplasms

Adv. Respir. Med. 2017; 85: 345-351

\section{Introduction}

A solitary pulmonary nodule (SPN) is a round lesion within the aerated lung visualized in chest imaging studies, it is a significant clinical, diagnostic, and economic problem, particularly when the finding is incidental. Since the 1990s, when multislice computed tomography (CT) technique became commonly available, the problem of incidentally detected lesions has increased in importance and frequency [1]. This is mostly due to the fact that the technique facilitates detection of lesions as small as 1-2 mm. According to European low-dose screening studies, the incidence rate of nodular lesions is $19.5 \%$ [2]. Worldwide incidence is estimated at $8-51 \%$ of scans, depending on the type of the scan, population and technical capabilities of the equipment $[3,4]$.

Most solitary pulmonary nodules are benign $[2,5]$; however, they may also be early- as well as advanced-stage malignant tumors. According to estimations, one in 13 males and one in 16 females will be diagnosed with lung cancer, with $20-30 \%$ of these patients being diagnosed on the basis of a single focal lesion [6].

Basic radiological characterisation of a visualized nodule depends on its X-ray attenuation (density), outline, size, and shape. All these parameters deliver much information on the nature of the lesion; however, do not provide final information of benign vs. malignant character of the lesion. The knowledge of the diagnostic options

Address for correspondence: Marcin Paśnik, National Tuberculosis and Lung Disease Research Institute, Warsaw, Poland, Płocka 26, 01-138, Warsaw, Poland, e-mail: mpasnik@gmail.com

DOI: 10.5603/ARM 2017.0059

Received: 07.09.2017

Copyright (C) 2017 PTChP

ISSN 2451-4934 
and schemes to be followed after detection of solitary pulmonary nodules is crucial to everyday pneumology practice.

\section{Pulmonary nodules - etiology}

Solitary pulmonary nodules may be classified according to their etiology into the following groups:

1) Neoplasms

— benign (e.g. hamartoma)

- malignant

- primary (lung cancer)

- secondary (metastases)

2) Inflammatory lesions

— infectious (e.g. round pneumonia)

- non-infectious (e.g. rheumatoid nodule)

3) Other (e.g. round atelectasis)

\section{Benign neoplastic lesions}

WHO classification lists several types of benign neoplastic lesions occurring in the lower respiratory tract $[7,8]$. The most common lesion of this type is hamartoma, a tumor of mesenchymal origin representing ca. $75 \%$ of benign tumors $[9,10]$. According to the 2015 WHO guidelines, hamartoma localized in the lung is classified as a neoplastic lesion in contrast to hamartomas found in other organs; therefore, reference to "lung hamartoma" is recommended to differentiate this entity [8]. Other types of benign tumors such as adenoma, lipoma, papilloma, fibroma are much less common.

\section{Malignant lesions}

Malignant neoplastic lesions are the most diverse subgroup of focal pulmonary lesions. Depending on the histological type, they may be divided into epithelial (squamous cell carcinoma, large-cell carcinoma, small-cell carcinoma, adenosquamous carcinoma, sarcomatoid carcinoma, carcinoid tumor, salivary gland tumor), mesenchymal, lymphoproliferative and miscellaneous ones. In addition, metastases into lungs, particularly occurring in the course of breast cancer, colon cancer, or renal cancer should be included in the group [11, 12].

Lung cancer requires a more detailed description as it is currently the most common malignancy in Poland. In recent years, it has been diagnosed in 1.2 million new patients every year worldwide; new cases in Poland sum up to ca. 16,000 of male and ca. 6,000 of female patients. Lung cancer is the most common cause of cancer -related deaths among women and men. In 2010, a total of 22,512 deaths were recorded, including
16,716 deaths of male patients and 6,177 deaths of female patients $[13,14]$. The risk of lung cancer depends mainly on active [6] or passive exposure to carcinogens in tobacco smoke (ca. $90 \%$ of all cases) [6, 15-18] as well as on certain physical and chemical environmental factors and genetic factors $[13,11]$.

Lung cancer develops in large bronchi or peripherally The peripheral form manifested by a solitary nodule is typical of adenocarcinoma. Metastases of lung cancer are most commonly found in the regional lymph nodes, liver, brain, contralateral lung, bones, and adrenal glands. Lung cancer may spread locally by infiltration of mediastinal structures, the diaphragm, pleura, and chest wall $[13,15,18]$.

\section{Inflammatory lesions}

This heterogeneous group includes all infectious and non-infectious diseases which may manifest as SPN detected in imaging studies. Major infectious diseases include bacterial pneumonia (particularly round pneumonia, which is more frequent in children), lung abscess, granulomatous infections - mycobacterial, fungal - and atypical infections.

Non-infectious focal inflammatory lesions develop in the course of diseases such as rheumatoid arthritis (rheumatoid nodules), granulomatosis with polyangiitis (solid or cavitating nodules) or sarcoidosis (conglomerates of small nodules).

\section{Other lesions}

Other lung diseases that may manifest as SPN include mainly round atelectasis and pulmonary infarction as well as pulmonary contusion, mucoid impaction, pulmonary sequestration, vascular malformation or intrapulmonary lymph node.

\section{Diagnostic imaging of nodules}

Diagnostic imaging techniques include plain chest X-ray, ultrasonography (USG), computed tomography (CT), magnetic resonance (MRI), and positron emission tomography (PET).

SPN's are usually detected in plain chest radiograph, as it is typically first-line imaging of choice. Posteroanterior (PA) and lateral X-ray images may provide information on size, shape, cavitation, rate of growth, and the presence of calcifications. Chest x-ray has low sensitivity. Despite the fact that it allows for detection of nodules as small as $5 \mathrm{~mm}$, lesions of more than $10 \mathrm{~mm}$ in diameter are usually identified [19]. 
One of the superiorities of CT imaging as contrasted with plain X-ray $[19,20]$ is that it facilitates detection of lesions $1-2 \mathrm{~mm}$ in size [21]. CT helps in better identification of the character and extent of lesion. In addition, CT makes easier the visualization of other thoracic structures possibly related to the detected nodule (e.g. enlarged mediastinal lymph nodes).

Ultrasonographic technique has limited ability of assessing solitary lesions due to the fact that lung aeration reduces its penetrability by ultrasound waves. The method, however, is useful in diagnosing subpleural lesions and lesions that infiltrate the thoracic wall.

MRI as a highly specialized and not easily available technique is not used in routine assessment of SPN's. However, due to its high tissue resolution, it is particularly useful in the assessment of local lesion advancement. Of all the aforementioned techniques, MRI is best capable of revealing the relationship and the presence of any infiltration of the surrounding structures (chest wall, mediastinum, large vessels, diaphragm). It is also the method of choice in the assessment of lung apex (Pancoast's) tumors [22, 23].

18F-Fluorodeoxyglucose (FDG) PET imaging of focal lesions combined with the CT scans is a well-studied and established method for evaluating ambiguous lesions larger than $1 \mathrm{~cm}$. Due to the sensitivity of $97 \%$ and specificity of $78 \%$ [24], PET/CT is recommended in some countries as the technique for routine assessment of potentially surgical focal lesions [22]. An important limitation of the method consists in the false negatives in cases of adenocarcinomas, carcinoids, and nodules smaller than $1 \mathrm{~cm}$, and false positives in cases of infectious and inflammatory lesions [24, 25].

An additional, supplemental tool that facilitates the assessment of the likelihood of malignancy of a nodular lesion consists of different mathematical and statistical models that combine imaging and clinical data. In recent years, numerous similar models were developed, mainly due to the widespread use of screening examinations and the availability of data obtained therefrom. The best known models include Bayesian Analysis as well as models proposed by the Mayo Clinic, the Fleischner Society, and the British Thoracic Society. Preliminary assessment of the probability of malignancy of a particular lesion, while being a potentially effective strategy for the decision-making process, is still approximate and requires individual evaluation.

\section{Radiological characteristics of focal lesions visualized in CT scans}

Radiological characterization of lesions should take into consideration the classification of focal lesions depending on various parameters such as their size, morphology (shape and outline), density measured by the X-ray attenuation expressed in Hounsfield units H.U., as well as the rate of growth. These types of classifications are aimed mainly at identification of lesions with a higher probability of malignancy.

\section{Size}

According to the guidelines of the Fleischner Society [5], a nodular lesion as visualized in a CT scan is a round lesion with the diameter of $<30$ $\mathrm{mm}$ localized within the aerated parenchyma of the lung. The size of the lesion translates to the preliminary evaluation of the malignancy which increases with the size; thus, about $80 \%$ of lesions larger than $20 \mathrm{~mm}$ are malignant as compared to as little as $1 \%$ for lesions sized $2-5 \mathrm{~mm}$. Tumors, or focal lesions $>30 \mathrm{~mm}$ in size, are to be considered malignant unless proven otherwise in diagnostic examinations [26-28].

\section{Density}

Nodules are classified as solid and non-solid (ground-glass opacity and ground-glass with a solid component, i.e. part-solid). Solid lesions represent a wide etiological spectrum from benign lesions such as hamartoma, through invasive cancers, to metastatic lesions (Fig. 1).

Non-solid nodules in more than one half of cases are benign and correspond to focal inflammatory lesions of post-inflammatory scars. Currently, however, much attention is paid to non-solid lesions since when discovered incidentally, they are more likely to correspond to malignant lesions than solid lesions of similar size [29-31].

Ground glass opacity nodules may correspond to a wide range of lesions. Tumors smaller than $<5 \mathrm{~mm}$ may represent atypical adenomatous hyperplasia $(\mathrm{AAH})$, while larger lesions with the diameter of $<30 \mathrm{~mm}$ may correspond to adenocarcinoma in situ (AIS) or minimally invasive adenocarcinoma (MIA). AAH and AIS are preinvasive lesions and the complete resection of $\mathrm{AAH}, \mathrm{AIS}$, and MIA nodules leads to the 5-year survival rate of $100 \%$.

More than $60 \%$ of semi-solid nodules are malignant in character [30] and may correspond to invasive adenocarcinoma of the lung, particu- 

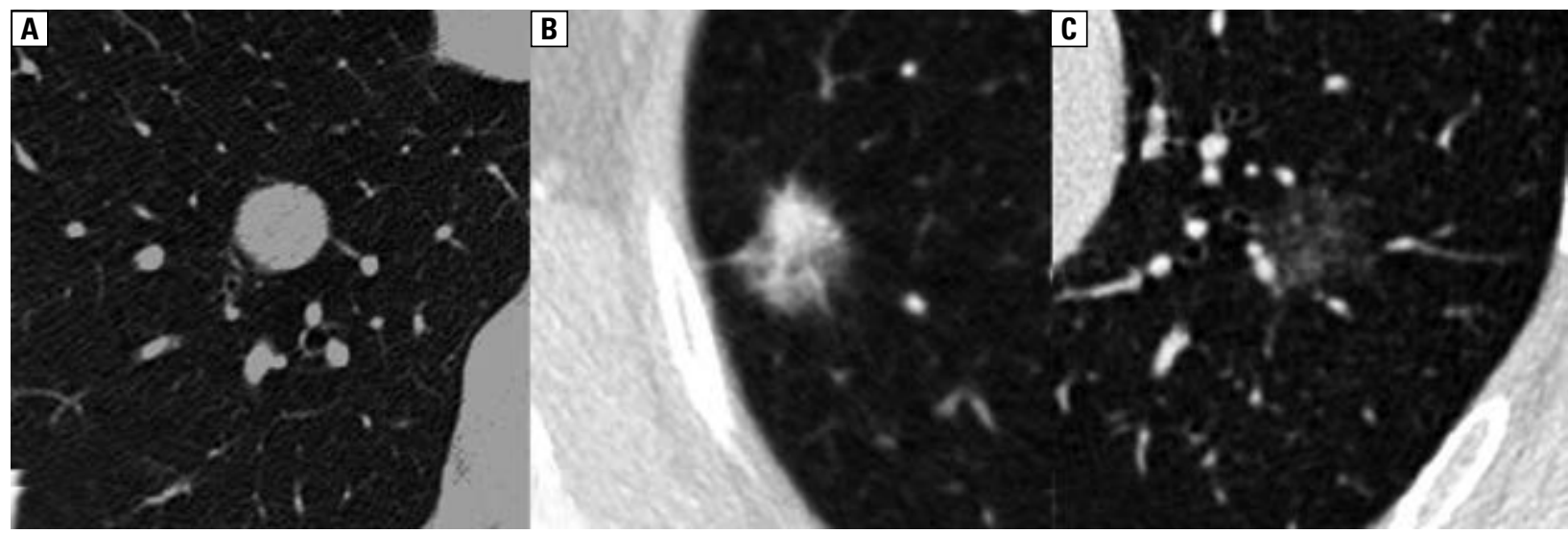

Figure 1. CT scans of solid (A), part-solid (B) and ground glass-type lesions (C)
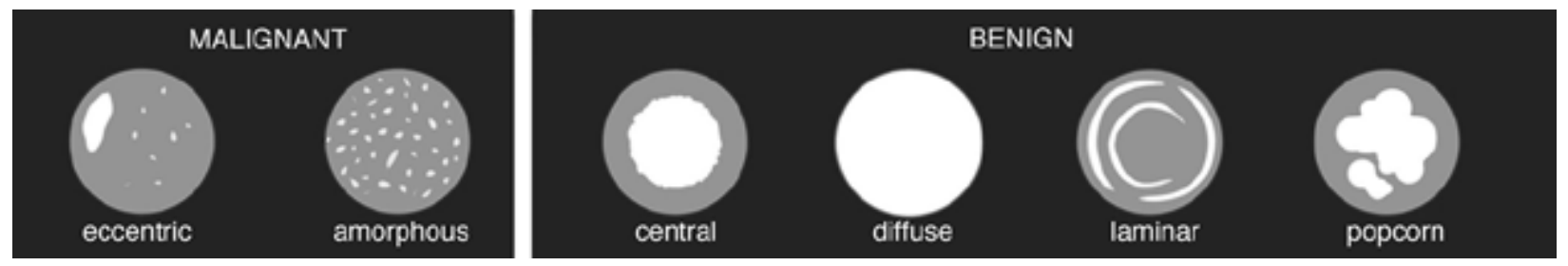

Figure 2. Schematic representation of calcifications

larly lepidic predominant adenocarcinoma (LPA) characterized by slow tumor growth.

\section{Calcifications}

The pattern of calcifications within a lesion may be indicative of its character. Complete or central calcification is indicative of a benign process, while eccentric or numerous tiny amorphous calcifications are suggestive of the process being malignant [32]. Calcifications are observed in about $10 \%$ of cancers; unfortunately, these may include large, central calcifications (Fig. 2) [32].

\section{Morphology}

The assessment of the morphology of a SPN includes its shape (round, oval, spicular, polycyclic, triangular), outline (smooth, blurred, the presence of ground-glass halo-sign around the lesion) and the presence of cavitation (Fig. 3).

The irregular, spicular shape is associated with the highest likelihood of the malignant character of the lesion. Round lesions with smooth margin are on the other end of the malignancy spectrum [33]. Triangular lesions in subpleural and perifissural locations usually correspond to normal, intrapulmonary lymph nodes [32]. Solid lesion surrounded by a halo ground glass-opacity is usually observed in the course of inflammatory disorders, commonly in angioinvasive aspergillo- sis; however, such findings may also be observed for metastases of melanoma or for adjacent pulmonary parenchyma being infiltrated by the primary lung tumor [34].

Cavitation is observed in benign lesions, mainly inflammatory (tuberculosis, fungal infection, granulomatosis with polyangiitis) but also in malignant lesions. Malignant vs. benign character of the lesion is indicated by the wall thickness walls up to $4 \mathrm{~mm}$ are in $92 \%$ indicative of benign lesion, while walls thicker than $15 \mathrm{~mm}$ are in $95 \%$ suggestive of malignancy [35].

\section{Growth rate}

The growth rate is determined from the time in which the lesion volume is doubled or its diameter is increased by ca. $25 \%$ (which also corresponds to the doubling of the volume).

According to general consensus, doubling of the volume of a focal lesion within less than one month or more than 18 months is indicative of a benign character of the process (either inflammatory or neoplastic). Solid lesions stable for 2 years are also considered benign (with volume doubling time being taken into consideration). However, one should keep in mind that this rule does not apply to non-solid lesions, which grow much slower with doubling time as long as 4 years [35]. An additional difficulty associated with the- 


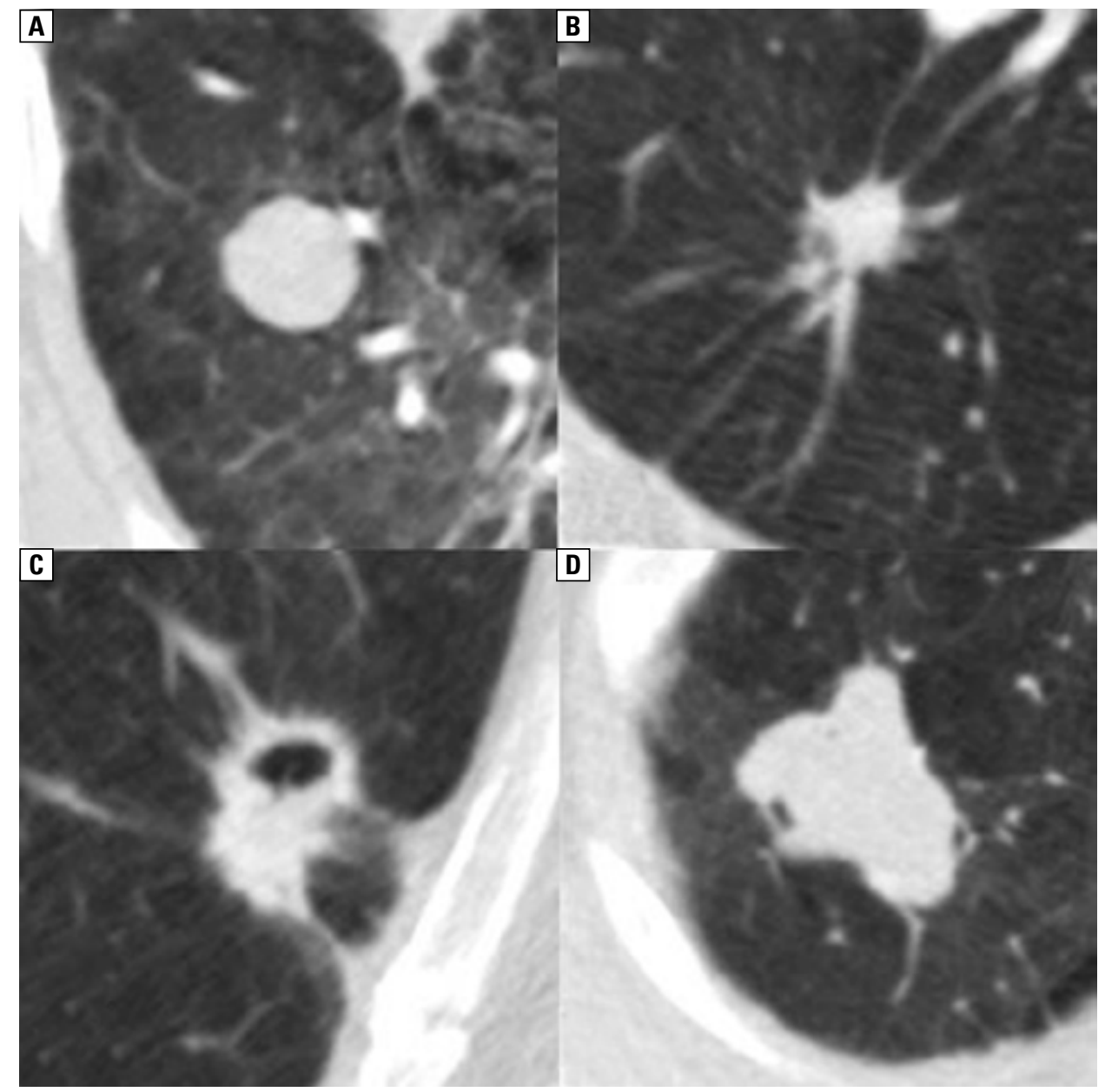

Figure 3. CT images of lesions of various morphology: smooth solid (A), spicular (B), cavitated (C), polycyclic (D)

se lesions is due to the problems with accurate and repeatable measurements of the solid and the ground glass opacity parts; therefore, computer assisted diagnosis (CAD) are used more and more commonly to achieve this end [36].

\section{Contrast enhancement}

The assessment of a solitary pulmonary nodule following administration of a contrast agent may provide additional information on the nature of the lesion since contrast enhancement is directly related to the lesions' vasculature and good vasculature is usually characteristic of malignant lesions [37, 38]. Full evaluation of the degree of enhancement requires a series of scans at intervals of several minutes. Nodular enhancement of less than 15 H.U. is suggestive of a benign lesion (false negatives include nodes with central necrosis and adenocarcinoma [37], while the enhancement of 20-60 H.U. is indicative of a malignant lesion [39]. Currently, dynamic studies are recommended to obtain information about the character of lesion enhancement. These studies allow for continuous assessment of the degree of contrast enhancement and the contrast washout rate [38]. Information similar to that available from dynamic studies may be obtained for a single scan by means of dual-energy imaging with contrast enhancement [40].

Unfortunately, no enhancement is pathognomonic for a particular benign or malignant lesion.

\section{Diagnostic management guidelines}

Numerous guidelines for the diagnostic management of nodular pulmonary lesions were developed in recent years in Europe and in the world. In Europe, the most common guidelines were proposed by the Fleischner Society. The most recent edition of the guidelines was proposed in March 2017 introducing a number of changes compared to the previous editions from 2005 and 2013 [41]. The guidelines are presented in Table 1. 
Table 1. Fleischner Society 2017 Guidelines for Management of Incidentally Detected Pulmonary Nodules in Adults [41]

\section{Solid nodules}

\begin{tabular}{|c|c|c|c|c|}
\hline $\begin{array}{l}\text { Nodule } \\
\text { Type }\end{array}$ & Size $<6 \mathrm{~mm}$ & Size 6-8 mm & Size $>8 \mathrm{~mm}$ & Comments \\
\hline \multicolumn{5}{|l|}{ Single } \\
\hline Low risk & $\begin{array}{l}\text { No routine } \\
\text { follow-up }\end{array}$ & $\begin{array}{l}\text { CT at } 6-12 \text { mon- } \\
\text { ths, then consider } \\
\text { CT at } \\
18-24 \text { months }\end{array}$ & $\begin{array}{l}\text { Consider CT at } 3 \\
\text { months, PET/CT, or } \\
\text { tissue sampling }\end{array}$ & $\begin{array}{l}\text { Nodules, } 6 \mathrm{~mm} \text { do not require routine follow-up, } \\
\text { but certain patients at high risk with suspicious } \\
\text { nodule morphology, upper lobe location, } \\
\text { or both may warrant 12-month follow-up }\end{array}$ \\
\hline High risk & $\begin{array}{l}\text { Optional CT at } \\
12 \text { months }\end{array}$ & $\begin{array}{l}\text { CT at } 6-12 \text { mon- } \\
\text { ths, then CT } \\
\text { at } 18-24 \text { months }\end{array}$ & $\begin{array}{l}\text { Consider } \mathrm{CT} \text { at } 3 \\
\text { months, } \mathrm{PET} / \mathrm{CT} \text {, } \\
\text { or tissue sampling }\end{array}$ & $\begin{array}{l}\text { Nodules, } 6 \mathrm{~mm} \text { do not require routine follow-up, but certain } \\
\text { patients at high risk with suspicious nodule morphology, upper } \\
\text { lobe location, or both may warrant 12-month follow-up }\end{array}$ \\
\hline \multicolumn{5}{|l|}{ Multiple } \\
\hline Low risk & $\begin{array}{l}\text { No routine } \\
\text { follow-up }\end{array}$ & $\begin{array}{l}\text { CT at } 3-6 \text { mon- } \\
\text { ths, then consider } \\
\text { CT at } \\
18-24 \text { months }\end{array}$ & $\begin{array}{l}\text { CT at } 3-6 \text { months, } \\
\text { then consider CT } \\
\text { at } 18-24 \text { months }\end{array}$ & $\begin{array}{l}\text { Use most suspicious nodule as guide to management. Follow } \\
\text {-up intervals may vary according to size and risk }\end{array}$ \\
\hline High risk & $\begin{array}{l}\text { Optional CT at } \\
12 \text { months }\end{array}$ & $\begin{array}{l}\text { CT at } 3-6 \text { mon- } \\
\text { ths, then } \\
\text { at } 18-24 \text { months }\end{array}$ & $\begin{array}{l}\text { CT at } 3-6 \text { months, } \\
\text { then at } 18-24 \\
\text { months }\end{array}$ & $\begin{array}{l}\text { Use most suspicious nodule as guide to management. Follow } \\
\text {-up intervals may vary according to size and risk }\end{array}$ \\
\hline \multicolumn{5}{|c|}{ Subsolid nodules } \\
\hline $\begin{array}{l}\text { Nodule } \\
\text { Type }\end{array}$ & Size $<6 \mathrm{~mm}$ & Size $\geq$ & 6 mm & Comments \\
\hline \multicolumn{5}{|l|}{ Single } \\
\hline $\begin{array}{l}\text { Ground } \\
\text { glass }\end{array}$ & $\begin{array}{l}\text { No routine } \\
\text { follow-up }\end{array}$ & $\begin{array}{l}\text { CT at 6-12 montl } \\
\text { sistence, then CT } \\
5 \text { ye }\end{array}$ & $\begin{array}{l}\text { s to confirm per- } \\
\text { every } 2 \text { years for } \\
\text { ars }\end{array}$ & $\begin{array}{l}\text { In certain suspicious nodules, } 6 \mathrm{~mm} \text {, consider follow-up at } 2 \text { and } \\
4 \text { years. If solid component(s) or growth develops, consider resection }\end{array}$ \\
\hline Part solid & $\begin{array}{l}\text { No routine } \\
\text { follow-up }\end{array}$ & $\begin{array}{l}\text { CT at 3-6 month } \\
\text { sistence. If unchan } \\
\text { ponent remains, } \\
\text { should be perfor }\end{array}$ & $\begin{array}{l}\text { to confirm per- } \\
\text { ed and solid com- } \\
\text { mm, annual CT } \\
\text { ned for } 5 \text { years }\end{array}$ & $\begin{array}{l}\text { In practice, part-solid nodules cannot be defined as such until } \\
6 \mathrm{~mm} \text {, and nodules, } 6 \mathrm{~mm} \text { do not usually require follow-up. } \\
\text { Persistent part-solid nodules with solid components } 6 \mathrm{~mm} \text { should } \\
\text { be considered highly suspicious }\end{array}$ \\
\hline Multiple & $\begin{array}{c}\text { CT at } 3-6 \\
\text { months. If sta- } \\
\text { ble, consider CT } \\
\text { at } 2 \text { and } \\
4 \text { years. }\end{array}$ & $\begin{array}{r}\text { CT at } 3-6 \text { mont } \\
\text { management ba } \\
\text { suspicious }\end{array}$ & $\begin{array}{l}\text { s. Subsequent } \\
\text { ed on the most } \\
\text { nodule(s) }\end{array}$ & $\begin{array}{l}\text { Multiple, } 6 \mathrm{~mm} \text { pure ground-glass nodules are usually benign, but } \\
\text { consider follow-up in selected patients at high risk at } 2 \text { and } 4 \text { years }\end{array}$ \\
\hline
\end{tabular}

\section{Summary}

Detection of a solitary pulmonary nodule is associated with a significant diagnostic dilemma. The radiological image of the lesion and its features including size, radiological density, shape and growth rate are insufficient for the final evaluation of its malignancy. Information obtained using more advanced imaging systems including PET, dynamic CT scans to assess the degree of enhancement, or MRI scans provide new yet often non-definitive data. Other risk factors such as age, smoking status or concomitant malignant diseases are also very important for the assessment of the malignancy of a particular lesion. Due to the complexity of the diagnostic process, the final decision on the management of each particular lesion is made on the basis of combination of the clinical risk and the radiological features, therefore multidisciplinary and individualised approach is required.

\section{Conflict of interest}

The authors declare no conflict of interest.

\section{References:}

1. Brandman S, Ko JP. Pulmonary nodule detection, characterization, and management with multidetector computed tomography. J Thorac Imaging. 2011; 26(2): 90-105, doi: 10.1097/ RTI.0b013e31821639a9, indexed in Pubmed: 21508732. 
2. Silva M, Pastorino U, Sverzellati N. Lung cancer screening with low-dose CT in Europe: strength and weakness of diverse independent screening trials. Clin Radiol. 2017; 72(5): 389-400, doi: 10.1016/j.crad.2016.12.021, indexed in Pubmed: 28168954.

3. Alpert JB, Lowry CM, Ko JP. Imaging the solitary pulmonary nodule. Clin Chest Med. 2015; 36(2): 161-78, vii, doi: 10.1016/j. ccm.2015.02.003, indexed in Pubmed: 26024598.

4. Kikano GE, Fabien A, Schilz R. Evaluation of the solitary pulmonary nodule. (2015. www.aafp.org/afp.

5. Hansell DM, Bankier AA, MacMahon H, et al. Fleischner Society: glossary of terms for thoracic imaging. Radiology. 2008; 246(3): 697-722, doi: 10.1148/radiol.2462070712, indexed in Pubmed: 18195376.

6. Siegelman SS, Khouri NF, Scott WW, et al. Pulmonary hamartoma: CT findings. Radiology. 1986; 160(2): 313-317, doi: 10.1148/radiology.160.2.3726106, indexed in Pubmed: 3726106.

7. Chojniak R, Isberner RK, Viana LM, et al. Computed tomography guided needle biopsy: experience from 1,300 procedures. Sao Paulo Med J. 2006; 124(1): 10-14, doi: /S151631802006000100003, indexed in Pubmed: 16612456.

8. Borczuk AC. Benign tumors and tumorlike conditions of the lung. Arch Pathol Lab Med. 2008; 132(7): 1133-1148, doi: 10.1043/1543-2165(2008)132[1133:BTATCO]2.0.CO;2, indexed in Pubmed: 18605767.

9. Travis WD, Brambilla E, Nicholson AG, et al. WHO Panel. The 2015 World Health Organization Classification of Lung Tumors: Impact of Genetic, Clinical and Radiologic Advances Since the 2004 Classification. J Thorac Oncol. 2015; 10(9): 1243-1260, doi: 10.1097/JTO.0000000000000630, indexed in Pubmed: 26291008.

10. Steele JD. The solitary pulmonary nodule. Report of a cooperative study of resected asymptomatic solitary pulmonary nodules in males. J Thorac Cardiovasc Surg. 1963; 46: 21-39, indexed in Pubmed: 14044162.

11. Arrigoni MG, Woolner LB, Bernatz PE, et al. Benign tumors of the lung. A ten-year surgical experience. J Thorac Cardiovasc Surg. 1970; 60(4): 589-599, indexed in Pubmed: 5511893.

12. Seo JB, Im JG, Goo JM, et al. Atypical pulmonary metastases: spectrum of radiologic findings. Radiographics. 2001; 21(2): 403-417, doi: 10.1148/radiographics.21.2.g01mr17403, indexed in Pubmed: 11259704.

13. Feuerstein IM, Jicha DL, Pass HI, et al. Pulmonary metastases: MR imaging with surgical correlation--a prospective study. Radiology. 1992; 182(1): 123-129, doi: 10.1148/radiology.182.1.1727274, indexed in Pubmed: 1727274.

14. Krzakowski M, Jassem J, Dziadziuszko R, et al. Zalecenia postępowania diagnostyczno-terapeutycznego w nowotworach złośliwych 2013 rok, Via Medica. ; 2013: 69-102.

15. Strauss GM. Bronchiogenic carcinoma. Textbook of pulmonary diseases, 6th ed. Philadelphia, PA: Lippincott-Raven Publishers. ; 1998.

16. Trichopoulos D, Mollo F, Tomatis L, et al. Active and passive smoking and pathological indicators of lung cancer risk in an autopsy study. JAMA. 1992; 268(13): 1697-1701, indexed in Pubmed: 1527879.

17. Fontham ET, Correa P, Reynolds P. Environmental tobacco smoke and lung cancer in nonsmoking women. A multicenter study. JAMA. 1994; 271: 1752-1759.

18. Wojciechowska U, Olasek P, Czauderna K, Didkowska J. Nowotwory złośliwe w Polsce w 2014 roku. Centrum Onkologii - Instytut, Warszawa 2016.

19. Winer-Muram HT. The solitary pulmonary nodule. Radiology. 2006; 239(1): 34-49, doi: 10.1148/radiol.2391050343, indexed in Pubmed: 16567482.

20. Klein JS, Zarka MA. Transthoracic needle biopsy: an overview. J Thorac Imaging. 1997; 12(4): 232-249, indexed in Pubmed: 9368219.

21. Honeybourne D, Babb J, Bowie P. British Thoracic Society guidelines on diagnostic flexible bronchoscopy. Thorax. 2001; 56 (Suppl 1): i1-21, indexed in Pubmed: 11158709.

22. Kundel HL. Predictive value and threshold detectability of lung tumors. Radiology. 1981; 139(1): 25-29, doi: 10.1148/radiology.139.1.7208937, indexed in Pubmed: 7208937.

23. National Institute for Health and Clinical Excellence. The Diagnosis and Treatment of Lung Cancer NICE Clinical Guideline 121.

24. Komaki R, Putnam JB, Walsh G, et al. The management of superior sulcus tumors. Semin Surg Oncol. 2000; 18(2): 152-164, indexed in Pubmed: 10657917.

25. Gould MK, Maclean CC, Kuschner WG, et al. Accuracy of positron emission tomography for diagnosis of pulmonary nodules and mass lesions: a meta-analysis. JAMA. 2001; 285(7): 914-924, indexed in Pubmed: 11180735.

26. Webb WR, Higgins CB. Thoracic imaging. Lippincott Williams \& Wilkins, Baltimore 2010.

27. Holland JF, Bast RC, Morton DL, Frei E, Kufe DW, Weichselbaum RR. Cancer medicine. William \& Wilkins, Baltimore 1997.

28. Khouri NF, Meziane MA, Zerhouni EA, et al. The solitary pulmonary nodule. Assessment, diagnosis, and management. Chest. 1987; 91(1): 128-133, indexed in Pubmed: 3792065.

29. MacMahon H, Austin JHM, Gamsu G, et al. Fleischner Society. Guidelines for management of small pulmonary nodules detected on CT scans: a statement from the Fleischner Society. Radiology. 2005; 237(2): 395-400, doi: 10.1148/radiol.2372041887, indexed in Pubmed: 16244247.

30. Henschke CI, Yankelevitz DF, Mirtcheva R, et al. CT screening for lung cancer: Frequency and significance of part-solid and nonsolid nodules. Am J Roentgenol. 2002; 178(5): 1053-1057, indexed in Pubmed: 10776886.

31. Truong MT, Ko JP, Rossi SE, et al. Update in the evaluation of the solitary pulmonary nodule. Radiographics. 2014; 34(6): 1658-1679, doi: 10.1148/rg.346130092, indexed in Pubmed: 25310422 .

32. Mahoney MC, Shipley RT, Corcoran HL, et al. CT demonstration of calcification in carcinoma of the lung. AJR Am J Roentgenol. 1990; 154(2): 255-258, doi: 10.2214/ajr.154.2.2153329, indexed in Pubmed: 2153329.

33. Li F, Sone S, Abe H, et al. Malignant versus benign nodules at CT screening for lung cancer: comparison of thin-section CT findings. Radiology. 2004; 233(3): 793-798, doi: 10.1148/ radiol.2333031018, indexed in Pubmed: 15498895.

34. Hyodo T, Kanazawa S, Dendo S, et al. Intrapulmonary lymph nodes: thin-section CT findings, pathological findings, and CT differential diagnosis from pulmonary metastatic nodules. Acta Med Okayama. 2004; 58(5): 235-240, doi: 10.18926/ AMO/32102, indexed in Pubmed: 15666992.

35. Woodring JH, Fried AM, Chuang VP. Solitary cavities of the lung: diagnostic implications of cavity wall thickness. AJR Am J Roentgenol. 1980; 135(6): 1269-1271, doi: 10.2214/ ajr.135.6.1269, indexed in Pubmed: 6779538.

36. Aoki T, Nakata H, Watanabe H, et al. Evolution of peripheral lung adenocarcinomas: CT findings correlated with histology and tumor doubling time. AJR Am J Roentgenol. 2000; 174(3): 763-768, doi: 10.2214/ajr.174.3.1740763, indexed in Pubmed: 10701622.

37. Henschke CI, Yankelevitz DF, Yip R, et al. Writing Committee for the I-ELCAP Investigators. Lung cancers diagnosed at annual CT screening: volume doubling times. Radiology. 2012; 263(2): 578-583, doi: 10.1148/radiol.12102489, indexed in Pubmed: 22454506

38. Swensen SJ, Brown LR, Colby TV, et al. Lung nodule enhancement at CT: prospective findings. Radiology. 1996; 201(2): 447-455, doi: 10.1148/radiology.201.2.8888239, indexed in Pubmed: 8888239 .

39. Ohno Y, Nishio M, Koyama H, et al. Dynamic contrast-enhanced CT and MRI for pulmonary nodule assessment. AJR Am J Roentgenol. 2014; 202(3): 515-529, doi: 10.2214/AJR.13.11888, indexed in Pubmed: 24555587.

40. Yamashita K, Matsunobe S, Tsuda T, et al. Solitary pulmonary nodule: preliminary study of evaluation with incremental dynamic CT. Radiology. 1995; 194(2): 399-405, doi: 10.1148/ radiology.194.2.7824717, indexed in Pubmed: 7824717.

41. Macmahon H, Naidich DP, Goo JM, et al. Special report: Guidelines for management of incidental pulmonary nodules MacMahon. Radiology. 2017; 284(284). 